\title{
LATENT STRUCTURE OF REFLECTIVE LEARNING AT THE HIGHER EDUCATIONAL INSTITUTION: MIXED METHODS RESEARCH RESULTS
}

\author{
Remigijus Bubnys \\ Šiauliai University, Lithuania
}

\begin{abstract}
The article presents results of the research, conducted using mixed methods research strategy: the reflective learning model as a prerequisite for curriculum development and improvement in university studies. The qualitative study was implemented using unstructured reflections, written by 65 prospective special educators studying at the university. The phenomenological hermeneutical method of data analysis enabled to disclose students' experiences as preconditions for reflective learning, continuing studies at the university, and reveal impact on changes in personal conceptions, based on reflection of experienced situations. The quantitative study, which was attended by 389 students, aimed to disclose general trends of students' reflective learning in theoretical and practical studies. Primary and secondary factor analyses enabled to disclose the latent structure of the investigated phenomenon - reflective learning. The constructed reflective learning model, based on prospective special educators' example, can be described by 7 key dimensions, which can be treated as main trends, seeking improvement of the curriculum, implementing reflective learning at the higher education institution, and development of students' reflection competency during studies.
\end{abstract}

Keywords: reflective learning, higher education, mixed methods research.

\section{Introduction}

Solving educational problems, it is emphasized that in the learning society the requirements for higher education are related to the development of learners' competencies enabling reflective, cooperation-based participation in public life and professional activities in various complex contexts and situations (Stefani et al., 2010). The discourse on learning at the higher educational institution requires the person to learn and understand his/her learning that has occured (Nicholls, 2001). Modern higher education studies must focus on the student, who is characterized as an active participant of the (self-) educational process: searching, experimenting, creating his/her theories. Teaching and learning become inseparable processes, providing the very learner with the opportunity to responsibly understand his/her own learning process.

Analyzing the process of specialist education, Seibert \& Daudelin (1999), empahsise that the higher educational institution should offer the environment creating favourable conditions for reflective learning. Reflective learning includes investigations of one's actions, professional development, interrelations of theory and practice, personal, social and political emancipation. The analysis of scientific sources (Osterman \& Kottkamp, 2004; Boud et al., 2005) 
demonstrated that reflective learning enabled students to combine theoretical and practical knowledge, which they acquire studying and doing their practice, build their personal theories and understanding about future professional activities. Reflective learning at the higher educational institution is characterized as an interactive process in which learners investigate their experiences, use reflection to steer from impulsive and routine activities, discover and unconsciously construct new meanings, insights, provide new perspectives; this is a process of integrating exisiting and new knowledge, applying theoretical knowledge in practice (Jarvis et al., 2004; Moon, 2004). Regardless of what kind of formal knowledge the learner will get in the learning process, he/she forms a peculiar understanding of the phenomenon or activity; i.e., creates his/her theories.

The process of learning and, therefore, reflection, is individual, stemming from personal views, attitudes and values (Moon, 2004). Often students' practical experience is confined to technical skills to be applied in specific situations. On the other hand, theoretical knowledge acquired at university is not related to practical activities. Thus, the need to integrate reflection on practice and theoretical studies at the university comes to prominence, focusing on the fact that modelling of reflective learning at the higher educational institution is a non-finite process. Developing reflection ideas, higher educational institutions educating prospective professionals can constantly adjust the curriculum, developing reflective learning and the student's as a reflective practitioner's competencies. The scientific problem formulated in the article can be expressed by one research question: What are the specific trends of modeling prospective specialists' reflective learning at the higher educational institution and what is their content?

The research subject: latent structure of reflective learning at the higher educational institution.

Theresearchaim to disclose latent structure of prospective professionals' reflective learning at the higher educational institution, identifying the most effective mechanisms of this model.

\section{Methodology}

The research process was carried out in accordance with stages of strategy of consistent procedures (see Fig. 1).

The study employed the mixed methods research strategy, based on the combined use of quantitative and qualitative methods, appying the strategy of consistent procedures, which reveals different characterisitcs of the same phenomenon, specifies and expands results (Greene \& Caracelli, 1997; Creswell, 2003). Application of the concept of mixed methods enabled to diagnose, reflect and highlight students' employed practical models during 
theoretical and practical studies and key factors influencing students' selfreflection and reflection on activities and studies.

\section{QUALITATIVE RESEARCH IN THE POPULATION OF PROSPECTIVE SPECIAL EDUCATORS}

Referring to reflections of lived situations, the disclosure of students' practical experiences as premises for reflective learning by continuing studies

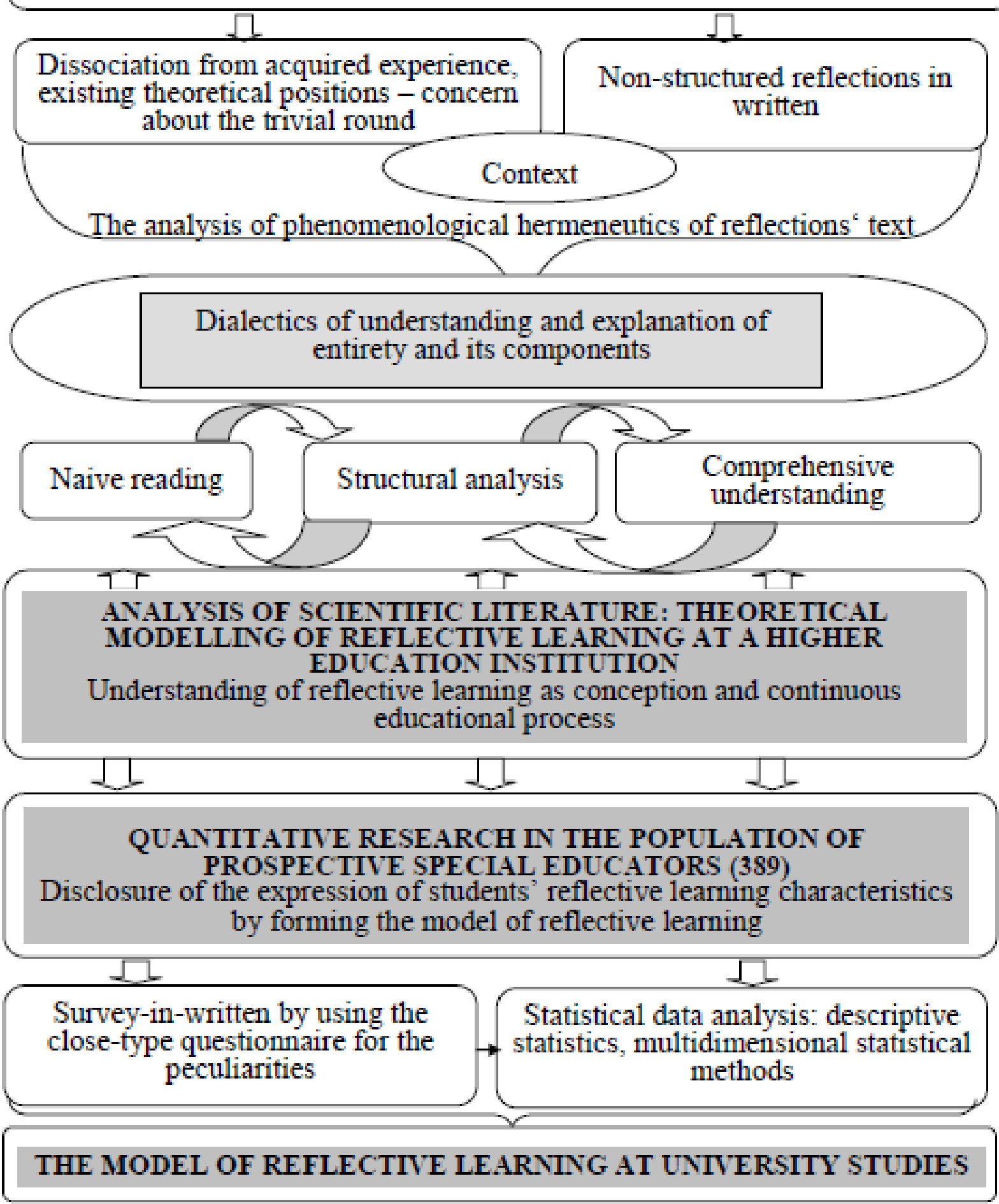

Figure 1. The Diagram of the Process of Mixed Method Empirical Research 
Mixed methods research results are presented in accordance with the specific chosen type of presentation of results, when theoretical, quantitative and qualitative research results are published in separate journals, giving clear references to other articles that have already been published by the author (Stange et al., 2006). This article presents final research results, having implemented the mixed methods research strategy.

The first stage of the research - the qualitative study - included nonstructured reflections in writing, written by 65 prospective special educators studying at the university, who were given open-ended questions. Phenomenological hermeneutic data analysis method enabled to disclose students' experiences as preconditions for reflective learning, continuing studies at the university, and as influences on changes in personal conceptions, based on reflection of experienced situations (Bubnys \& Žydžiūnaitè, 2007; Bubnys \& Žydžiūnaite, 2008; Bubnys, 2011) . $^{6}$

Research literature analysis was performed following the qualitative study stage as a connecting link between qualitative study and quantitative study. Qualitative study results serve as primary information for selection of sources and also seeking to ground obtained results (Bubnys, 2007; Bubnys \& Tuominienè, 2008; Bubnys \& Žydžiūnaite, 2010; Bubnys, 2012).

The quantitative study was implemented in order to highlight manifestation of students' reflective learning dimensions, forming the reflective learning model. Operationalisation of the research subject, based on scientific analysis of sources and qualitative study results, was followed by preparation of the questionnaire. The study involved 389 students, aiming to reveal general trends of students' reflective learning in theoretical and practical studies. Peculiarities of manifestation of reflective learning characteristics were disclosed applying descriptive statistics, which was the basis of primary quantitative data processing: calculation of frequencies, data percentages, means, standard deviation, mode, median. Multivariate statistical methods: factor analysis, when processing the data the exploratory and confirmatory factor analysis were applied. Qualitative study results reveal peculiarities of manifestation of prospective special educators' reflective learning characteristics (Bubnys \& Gudonis, 2009; Bubnys, 2010).

\section{Latent Structure of Reflective Learning in University Studies}

Primary and secondary factor analyses enabled to disclose the latent structure of the investigated phenomenon - reflective learning (see Fig. 2). The quantitative study extends and supplements the results of the qualitative study, disclosing trends of reflection on student experience and its integration in theoretical and practical studies at the university in relation to other participants of the educational process.

\footnotetext{
${ }^{6}$ There are references to the results of published studies of every stage
} 


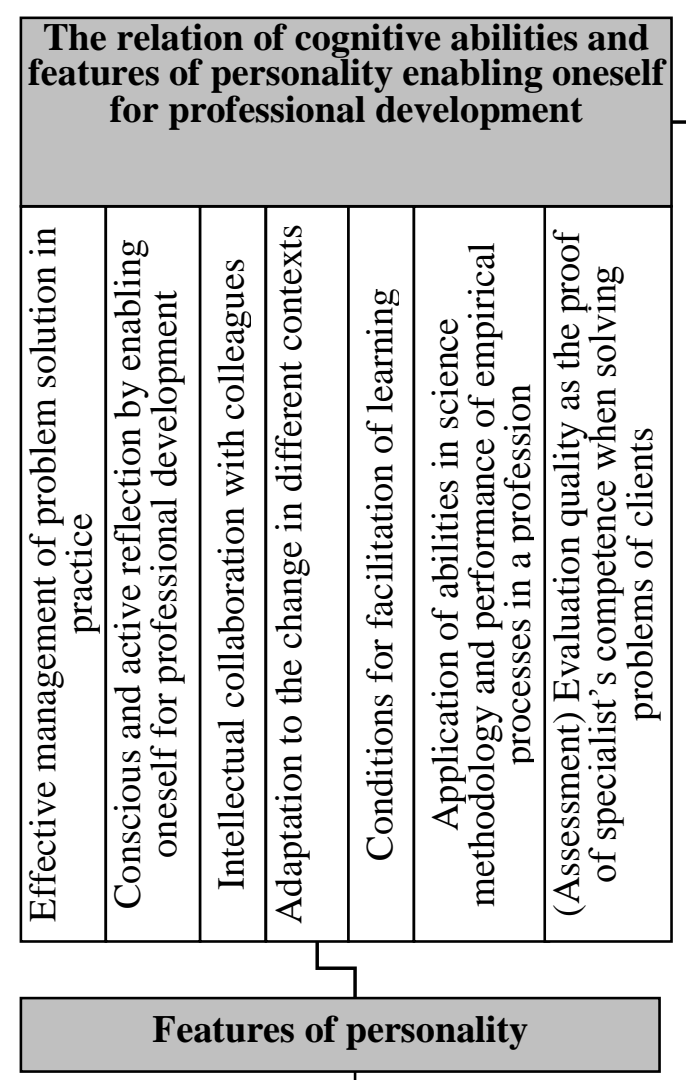

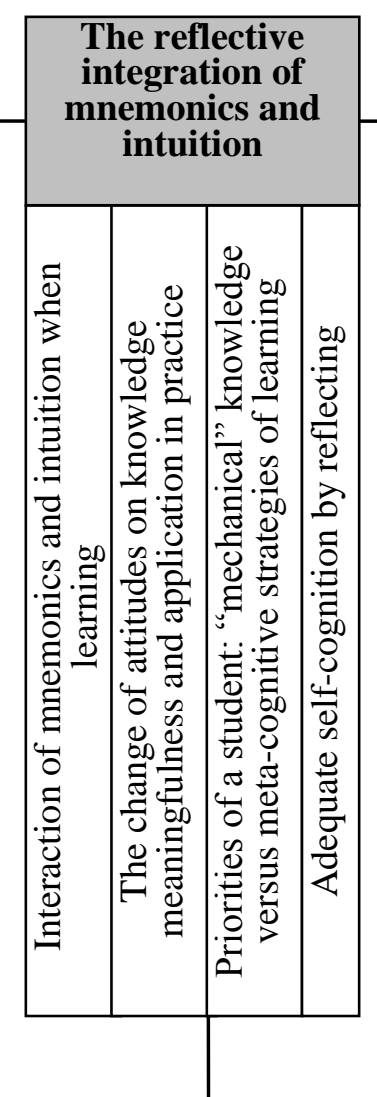

Openness equal relationship and teacher's competence - premises for students' critical thinking and reflection on acquired experience pedagogical competence by referring to mutual feedback in creating conditions for students' individual and group reflection

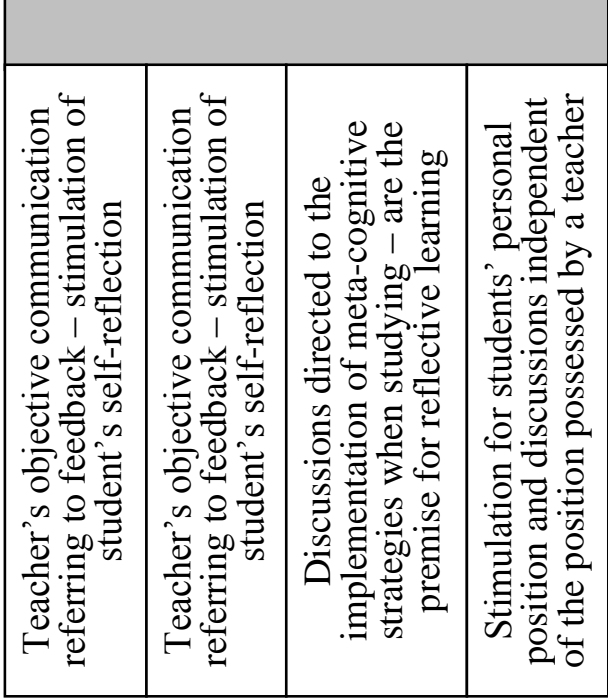

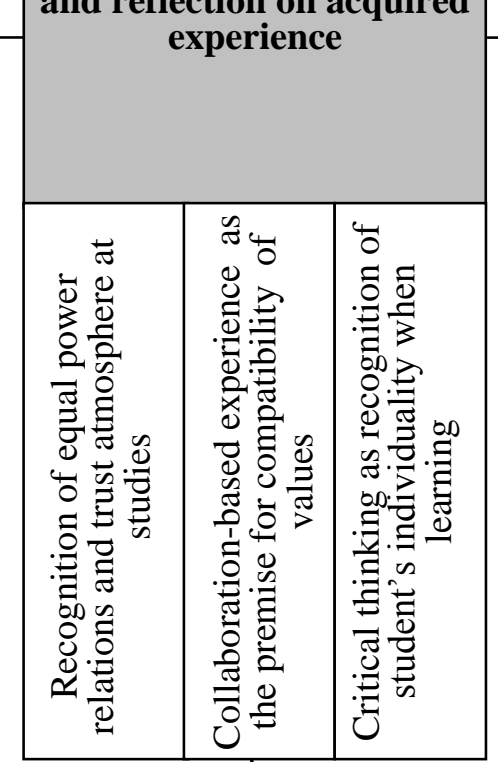

The analysis of the results of performed activities -

reflection on the $S E L F$ and practice by assessing the value of theory and practice

\begin{tabular}{|c|c|c|c|c|}
\hline 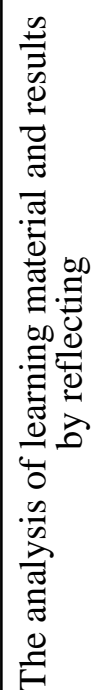 & 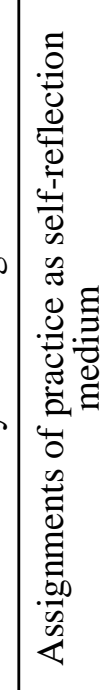 & 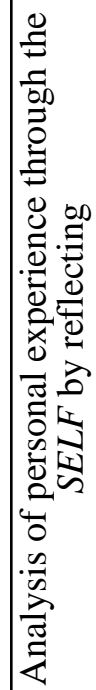 & 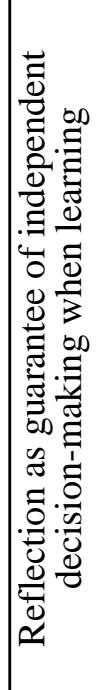 & 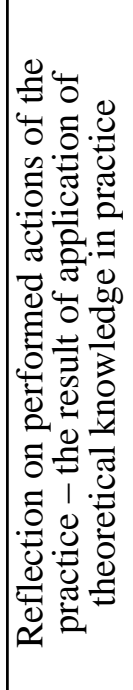 \\
\hline
\end{tabular}

\section{Personal activity student at practical and theoretical studies - the stimulus for individual and group reflection when realizing positive social relations}

Interaction of theoretical and practical fields of learning through contemplation and group reflections
Close interrelationship of colleagues studying together as the premise for successful learning
Personal activity during practice as the premise of learning from others' experience 
The constructed reflective learning model, based on the example of prospective special educators, can be described in seven key dimensions.

The link between cognitive abilities and personality traits, empowering oneself for professional development. The dimension is characterized as a dimension of prospective professionals' competence development, empowering the prospective specialist for professional development. The main focus falls on cognitive abilities and personality traits and their interrelationship. The first dimension reveals that students relate essential traits of the student's personality to moral (ethical) approaches, positive partnership, which is grounded on cooperation with all persons involved in the educational process. Distinguished groups of abilities and personality traits create preconditions for corresponding modelling of the teaching/learning process in university studies so that these abilities and personality traits are developed and create preconditions for reflective learning both during studies and in the future professional activity.

Reflective integration of memorization and intuition. This dimension is defined as interrelation of student's absorbed knowledge during studies and personal approaches, as a choice of learning peculiarities (habits), i.e., specific learning strategies while studying. Successful reflective learning at the higher educational institution includes the learner's intellect, emotions, intuition and lived sensory experience. It is important that during learning all these features should be combined with each other because this would enhance meaningfulness of learning and knowledge absorption. Thus, students are not passive recipients of knowledge, when learning outcomes are determined by the quantity of knowledge and its mechanical mastering. They are active developers and initiators of their system of knowledge. The student's priorities ("mechanical" knowledge versus metacognitive learning strategies) determine the student's approaches towards obtained knowledge. Reflective mastering of theoretical knowledge, deepening in the content of knowledge and its linking with personal experience enable the student to change his/her attitudes towards the very learning process and towards his/her as a professional's development. Intuitive guess and learning by heart are among students' most often used ways of memorising new materials. Intuitive knowledge absorption without reflective thinking becomes accidental and unrelated to the student's direct experience and experienced emotions.

The analysis of results of performed activities: reflection on the self and practice, evaluating the value of theory and practice. This dimension includes reflection of personal experience through one's self, analysis of learning outcomes through reflection, application of practical tasks as measures of selfreflection in the educational process, distinguishing the result of reflection as a guarantee of students' independent decisions and of application of theoretical knowledge in practice.

Planning learning activities, it is necessary to draw attention to the structure and content of the course, which are treated as the most important elements of 
the reflective learning process (Peltier et al., 2005). Students must be provided with conditions to analyze study materials, percieve the essence of tasks and, most importantly, it must be foreseen that they discover personal benefit of given tasks for themselves as a prospective professionals. It becomes relevant to appropriately distribute time for individual tasks during the course. In the reflective model most of the time has to be allocated for refection and evaluation of learning achievements and for discussion of knowledge application possibilities in practice.

Emphasising the value of theory and practice and interconnection of these areas while learning, the type and purposiveness of tasks for students that they perform during practice, gain relevance. It is important that students should percieve the benefit and purpose of notes, which they write down during their practice. Practice supervisors together with students should exhaustively discuss value and necessity of assigned tasks, their benefits for the student's personal growth, professional development or changes in personal approaches and values.

Realization of the teachers' pedagogical competency, based on mutual feedback, enabling students' individual and group reflection. The dimension puts emphasis on the importance of the teacher's pedagogical competency, creating corresponding conditions for implementation of reflection in the study process. Creating reflective learning environment at the higher educational institution, it is important that the teacher should understand that teaching constitutes creation of corresponding conditions for students to learn. The teacher's subject-based communication that is grounded on feedback determines teacher-student parity relationships. The reflective cooperation-based learning process provides opportunities for the student to discuss issues of concern with teachers of individual subjects and to receive effective feedback about effectiveness and results of learning, which helps students to plan their own learning pace and time because teachers help students to understand their own learning; i.e., the system of knowledge, its interrelations and meaningfulness. Efficient feedback promotes the student's self-reflection on himself/herself as a learner, on his/her learning habits, obtained knowledge and its practical value, encourages assessessment of personal learning achievements, future plans and prospects.

Discussions focused on implementation of metacognitive strategies create preconditions for reflective learning (Efklides, 2008), therefore, the teacher should choose such teaching methods which would promote interest in the delivered subject. Discussions with students on ways and strategies of learning the subject help students to discover their own learning style and type. The importance of the teacher as an assistant and facilitator comes to prominence because the teacher has to allocate sufficient time for analysing students' difficulties in the learning process and coping with them. A lot of time in the learning process has to be allocated for discussions about students' performed works and tasks, type and criteria of evaluation. 
Openness, tantamount relationships and the teacher's competence as preconditions for students' critical thinking and reflection on acquired experience. The dimension discloses the importance of tantamount teacherstudent relationships, grounded on mutual openness, for the development of students' critical thinking and reflection on acquired experience.

Critical thinking is a critical factor in reflective learning because learning involves complex activities (Black, 2005; Choy \& Cheah, 2009). The essential problem is that students of the higher educational institution have too little or no opportunities to systematically reflect using their own modelled or lived experience, fostering critical thinking skills, which they as prospective professionals need. The authoritarian teaching style, "closed" type of interrelationships and too high requirements for students determine students' conformist learning manifestations: they avoid sharing certain information about themselves with teachers due to unwillingness to be misunderstood; they seek to please teachers, refusing of their own approaches, and accept knowledge of the delivered subject as unquestionable truth.

Students have to be provided with sufficient assistance, grounded on tantamount and open interrelationships, forming learning to learn skills, which are particularly important for a reflective professional. Reflecting independently or assisted by specialists of the higher educational institution, students are getting used to identify their approaches, attitudes and values, integrate new understanding and formulate generalizations, which would enable them to make positive changes in their future professional activity situations. Teachers should not treat difficulties faced by students as a sign indicating learners' weaknesses; on the contrary, this should be a motive to encourage students to reflect on their learning, discovering reasons of these difficulties and foreseeing possible solutions. Both the teacher's disposition, his/her reflection ability and the striving that students follow their example are important.

Clear tasks, given by the teacher, highlighting positive aspects in students' versatile practice and promoting mutual feedback. This dimension focuses on the student's as a learner's experiences gained together with professionals in the practice placement, grounds purposiveness of practice tasks developing students' reflection competency. The main objective that the learner and his/her supervisor should pursue is transfer of experience and assistance, cognising peculiarities of the special educator's profession, applying theoretical knowledge in practice.

During practice the ability to apply theoretical knowledge, reflection and critical-analytical thinking abilities are formed in the student's activities, which are directly related to the tasks to be performed by the student in order to account for practice. Reflective writing and diary methods are the main instruments to analyze practice experience (Moon, 1999); however, the quantitative study results disclosed that in many cases practice diaries became a formal descriptive document rather than the analytical document. Often the 
analysis of experience in the diary is unreal and contrived; therefore, during practice students should be provided with conditions enabling them to experience situations that would be directly related to the task. Practice supervisor should help to create such conditions, comprehensively analysing tasks given for the student. Reflection on learning requires that students should evaluate performed tasks in accordance with clear criteria so that they can compare their progress with goals, which had been formulated in cooperation with teachers and/or practice supervisors. Clarity of practice tasks, their type and perception of their importance would promote students to evaluate their experiences anew and analyze their abilities and perception. Self-evaluation should shed new light on the already existing knowledge and acquired experience.

The student's personal activeness in practical and theoretical studies as a stimulus for individual and group reflection, implementing positive social relationships. The dimension includes the student's personal activeness, analyzing his/her learning experience and maintaining close, understandingbased interrelationships with group colleagues/students, teachers and practitioners.

The student's personal activeness and aspiration to share personal experience and learn from other persons' experience through cooperation create preconditions for emergence of reflective learning. The ability to share experience acquired during practice with teachers of individual subjects enables students to analyse the taken over experience comprehensively and from different perspectives. Efficacy of reflective learning is determined both by relationships between the teacher, educators of the institution, students and by links between the very learners- practitioners. Cooperation of the latter in the reflective learning process is emphasised by Dempsey et al., (2001), who state that sharing ideas and views with others who had lived similar experience is the basis of reflection.

To sum up, it should be stated that the constructed reflective learning model discloses key dimensions, which can be treated as key trends of improving the curriculum, implementing reflective learning at the higher educational institution and improving students' reflection competency during studies. It must be emphasised that modelling of reflective learning at the higher educational institution is a non-finite process. Conceptual modelling forms the perception that this is a contextual and situational process, which becomes meaningful only in the presence of empirical data and interpretation of subjects' experience. Continuous analysis of accumulated data enables students to deeper understand their learning and their prospective professional activity, and, based on reflection results, to correct their own actions. Accordingly, higher educational institutions, applying reflection in the teaching/learning process, can make adjustments in their curriculum. 


\section{Conclusions}

Dimensions of the model are to be considered as trends improving education of special educators, modelling vocational education curriculum at the higher educational institution at the levels of theoretical studies (academic), practical studies (practical) and at the student's personal (individual) level.

Reflective learning in university studies is modelled considering clusters of cognitive abilities and personality traits, related to the prospective professional's personality maturation and professional development, which are projected by students as being relevant for the prospective special educator. The established key groups of abilities representing the dimension development of competencies and personality traits outline the trends of education of the prospective specialist, provide for the development of his/her abilities of conscious and active reflection on action and in action, abilities of creating conditions to facilitate learning and effectively solve problems in practice.

The dimensions of the model include the pedagogical-didactic competency of the teacher and practitioners. The interaction of the university teacher, educator-practitioner and student, based on mutual trust and openness, subjectbased cooperation create prerequisites for the development of the student's critical thinking. Dimensions distinguished at academic and practical levels distinguish themselves by integrity and overlap. Reflection on the self, on learning materials and results of analysis are to be underlined in the content of the latter. The parameter the student's personal activeness during studies is to be emphasised, disclosing the importance of manifestation of personal motivation for individual and group reflection, implementing positive social relations with colleagues.

\section{References}

Black, S. (2005). Teaching students to think critically. The Education Digest, 70(6), 42-47.

Boud, D., Keogh, R., Walker, D. (2005). Reflection: Turning Experience into Learning. London and New York: RoutledgeFalmer.

Bubnys R. \& Tuominienè J. (2008). Studentu asmeninio augimo prielaidos taikant reflektyvaus dienoraščio / žurnalo metodą studiju procese. Ugdymo psichologija, 19, $59-67$.

Bubnys, R. (2007). Mokymosi lygių ivvairovė kaip reflektyvaus ugdymo aukštojoje mokykloje prielaida. Ugdymo psichologija, 18, 61-68.

Bubnys, R. (2010). Veiklos reflektavimo ir mokymosi teorinèse studijose iniversitete integralumas. Pedagogika, 99, 38-44.

Bubnys, R. (2011). Reflective Learning in the Training of Prospective Specialists at a Higher Education Institution. In. Beyond Fragmentation: Didactics, Learning and Teaching in Europe / Brian Hudson, Meinert A. Meyer (eds.) 2011, p. 139-153. Opladen \& Farmington Hills: Barbara Budrich Publishers.

Bubnys, R. (2012). Reflektyvaus mokymo(si) metodu diegimo aukštojoje mokykloje metodika: refleksija kaip besimokančiuju asmeninès ir profesinès raidos didaktinis metodas. Šiauliai: Šiaulių kolegijos leidybos centras. 


\section{SOCIETY. INTEGRATION. EDUCATION. Volume I}

Bubnys, R. \& Gudonis, V. (2009). Prospective Special Educators' Reflection on Personal Experience and its Integration in Practical Studies in Higher School. Special Education, 2 (21), 91-98.

Bubnys, R. \& Žydžiūnaitė, V. (2007). Experiences of Prospective Special Pedagogues in Practical Studies at a Higher School: Results of the Analysis of Written Reflections. Specialusis ugdymas, 2 (17), 40-50.

Bubnys, R. \& Žydžiūnaitè, V. (2008). Reflektuojančio būsimo specialiojo pedagogo profesinio apsisprendimo patirtys. Mokytoju ugdymas, 12 (2), 80-94.

Bubnys, R., Žydžiūnaite, V. (2010). Reflective Learning Models in the Context of Higher Education: Concept Analysis. Problems of Education in the 21st Century (Issues in Educational Research-2010), 20, 58-70.

Choy, S. C. \& Cheah, P. K. (2009). Teacher perceptions of critical thinking among students and its influence on higher education. International Journal of Teaching and Learning in Higher Education, 20(2), 198-206.

Creswell, J. (2003). Research design. Qualitative, quantitative and mixed methods approach. Thousand Oaks, London, New Delhi: SAGE Publications.

Dempsey, M., Halton, C., Murphy, M. (2001). Reflective learning in social work education: scaffolding the process. Social Work Education, 20 (6), 631-641.

Efklides, A. (2008). Metacognition: defining its facets and levels of functioning in relation to self-regulation and co-regulation. European Psychologist, 13(4), 277-287.

Greene, J. \& Caracelli, V. (1997). Defining and describing the paradigm issue in mixedmethod evaluation. In J. Greene and V. Caracelli (eds.). Advances in mixed-method evaluation: The challenges and benefits of integrating diverse paradigms. New Directions for Program Evaluation, 74, 5-18. San Francisco, CA: Jossey-Bass

Jarvis, P., Holford, J., Griffin, C. (2004). The Theory and Practice of Learning. London: Routledge Falmer.

Moon, J. (1999). Learning Journals. A Handbook for Academics, Students and Professional Development. London: Kogan Page.

Moon, J. A. (2004). A Handbook of Reflective and Experiential Learning. Theory and Practice. London and New York.

Nicholls, G. (2001). Professional Development in Higher Education. New Dimensions and Directions. London: Kogan Page.

Osterman, K. F. \& Kottkamp, R. B. (2004). Reflective Practice for Educators. Professional Development to Improve Student Learning. California: Corwin Press.

Peltier, J., Hay, A., Drago W. 2005. The Reflective Learning Continuum: Reflecting on Reflection. Journal of Marketing Education, 27 (3): 250-263.

Seibert, K., Daudelin, W. (1999). The role of reflection in managerial learning: Theory, research, and practice. Westport, CT: Quorum.

Stange, K. C., Crabtree, B. F., Miller, W. L. (2006). Publishing Multimethod Research. Annals of Family Medicine, 4 (4), 292-294.

Stefani, L., Clarke, J., Littlejohn, A. (2000). Developing a Student-Centred Approach to Reflective Learning. Innovations in Education and Training International, 37 (2), 163171. 